\title{
The Impact Of The Sarbanes-Oxley Act Of 2002 On The Business And Accounting Curriculums
}

Ronald O. Reed, (E-mail: ronald.reed@unco.edu), University of Northern Colorado Charles Bullock, University of Houston, Victoria Gene Johnson, Louisiana Tech University

Vish Iyer, University of Northern Colorado

\begin{abstract}
Business and accounting curriculums are designed to educate and train future business professionals and leaders. When Congress passed SOX in 2002, it dramatically impacted the responsibilities of corporate executives and CPAs and consequently required corresponding changes in the business schools prepare students to assume these roles. Because the Act changed the manner in which corporate decisions are made and how corporate organizations are governed and because of its impact on corporate business and CPA firms, it required business schools to modify the curriculums in business and accounting. This paper demonstrates the impact on the undergraduate business and accounting programs. In most cases, it is suggested that SOX material be integrated into existing courses because of the various constraints on undergraduate programs.
\end{abstract}

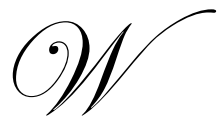

henever U.S. managers have perpetrated a major fraud or deceived the investing public or external auditors have failed to discover that fraud or deceit, Congress has reacted by issuing new securities laws that amend the 1933 or 1934 Securities Acts. In most cases, past amendments have placed blame on management for its behavior, have enacted severe criminal punishments, and have imposed liability and criminal punishments on the CPAs who audited these organizations. However, such past legislation did not eliminate corporate fraud or the failures of CPAs to detect the problems. In fact, it seemed federal authorities paid little attention to and failed to enforce the previous laws regulating corporate behavior. In the late 1990s and early 2000, a significant number of the corporate financial statement frauds and misrepresentations led to billions of dollars of investor losses in the marketplace. Highly publicized fraud cases, such as WorldCom, Enron, Tyco, Adelphia, Qwest, and others created such negative public reaction that Congress was forced to react with the passage of the SarbanesOxley Act of 2002 (SOX). In order to restore investor confidence in the stock markets, the New York Stock Exchange (NYSE) and NASDAQ adopted new listing standards requiring corporate boards of directors to be more independent of management and mandating shareholder approval of equity compensation plans. The Securities and Exchange Commission (SEC) also tightened the disclosure rules for executive compensation plans and imposed new rules of professional conduct on corporate lawyers and accountants. The new laws, rules, and regulations issued establish a level of transparency in the financial reporting process and corporate governance process.

SOX and the related regulatory changes significantly reshape the behavioral landscape for publicly-held businesses and CPA firms. By creating additional oversight of the CPA firms that audit and provide services to publicly-held businesses, it changed the manner in which external auditors are appointed and the services they can provide; it required certification of financial statements and internal control systems by the CEO and CFO; it increased the penalties for corporate fraud by management; moved many corporate governance issues away from state control to more federal oversight; and regulated many other aspects of corporate and CPA firm behavior. As a result, SOX and the related regulatory changes have had and will continue to have a significant impact on businesses, and will consequently transform business curricula, especially the accounting, finance, information systems, and management curricula. SOX has redefined issues in areas of corporate governance, ethics, internal control systems, 
process management, and audit approaches, and it has established new audit standard setting organizations. These redefined areas of corporate and CPA firm behavior have direct impacts on business and accounting programs.

All business majors at both the undergraduate and graduate levels who enter the business world will be impacted by SOX and need to have a basic understanding of the new law. Whether the student plans a career in senior management, on a board of directors, or as an employee of an organization, the financial literacy and transparency of business processes need to be understood. Senior executives of public companies and all of their employees have to accept responsibilities for the financial information and the processes that produce that information, thus fully understand the Act.

The purpose of this paper is to discuss the impact of SOX and the related regulatory changes have on undergraduate business and four-year accounting programs. This paper presents a brief summary of SOX and the regulatory changes and explains how business courses are likely to be impacted. This paper is directed at undergraduate programs because graduate and five-year accounting programs have additional time and possible courses that can be directed towards covering the requirements of the entire Act. This paper has significance because many undergraduate business and accounting programs have constraints, and this paper presents an integrated strategy for implementing SOX across the curriculum in an effort to overcome the constraints imposed on most undergraduate business and accounting programs. This approach provides coverage of SOX in courses where the material is most relevant to both accounting and non-accounting majors.

\section{CONSTRAINTS OF UNDERGRADUATE BUSINESS PROGRAMS}

One of the biggest constraints that many undergraduate business programs have is that they have credit hour limitations imposed upon them by the university or even by the state where they are located: in many states, the undergraduate program will most likely be limited to 120 semester credit hours. This issue will be discussed later in the section related to the impact on the business and accounting curriculums. Furthermore, AACSB accredited business and accounting programs may have further constraints imposed because of the credit hour allocations between business and nonbusiness hours, and within business schools there may be limits on credit hours within major discipline area. Therefore, many undergraduate business programs will have a challenge dealing with the incorporation of SOX material into their curriculum. They most likely will not be able to add courses to address this new material because of credit hour limitations, but will likely have to incorporate the material into existing courses. Professors will have to decide which current material is more worthy of keeping in a course and which material should be removed to include the more current and necessary SOX material.

Some of the textbooks relevant to SOX material are dealing with this same issue. The authors of these textbooks try to determine the Act's impact on the material in the text. The question remains, how much of SOX material should authors incorporate into a revised text or should they take a fresh approach and write a new text that addresses the material from the beginning? We do see textbooks directly aimed at SOX. But, again, they are often supplemental to the required textbook for the class and may not be adopted. There are significant numbers of websites that have very useful information about SOX. Obviously, the SEC website has the full Act and the "BigFour” accounting firms' websites have information. Table 1 provides a list of possible websites for SOX and related information.

Another problem that exists for undergraduate programs is the level of professors' knowledge about SOX and their realization about the depth of impact the Act has on their curriculum. Some specific areas in the business program, such as accounting and finance, are directly impacted and the faculty may be familiar with and knowledgeable about the Act. However, other disciplines may not be directly impacted, and as a result their faculty are not familiar with the Act at all, such as in the management, marketing, and information systems.

There are no easy answers to the questions about incorporating SOX into the undergraduate business curriculum. However, it is our belief that SOX will be a permanent Act. Thus, it needs to be addressed in current business curriculums. Many business professionals try to emphasize the high cost of implementing some of the provisions of SOX, especially Section 404, Management Assessment of Internal Control. A number of surveys to 
publicly held companies have found that Section 404 has cost American corporations billions of dollars, which ultimately impacts competition and prices to consumers. However, because a few corporate business leaders created ethical problems for the large number of ethical leaders, publicly-held corporations had inadequate systems of internal controls to prevent and detect fraud and misrepresentations in the financial statements, and the external auditors failed to detect the fraud, errors, or irregularities, SOX addresses these issues and the places a high level of corporate responsibility on management and the CPA firms.

\section{POTENTIAL IMPACT ON BUSINESS CURRICULUM}

Most undergraduate business programs are generally 120 credit hours. In those 120 credit hours, many programs require 60 credit hours outside the business program in general education and 60 credit hours within the business program. Those courses in the business program are divided between the business core courses and courses in the major area of study. The business core generally consists of the following courses:

$-\quad$ Two accounting courses (Financial and Managerial Accounting)
- $\quad$ Two economics courses (Macro and Microeconomics)
- $\quad$ One finance course
$\quad \quad$ One management course
- $\quad$ One information systems course
$\quad \quad$ One marketing course
- One or two statistics courses

Any knowledge of SOX that must be imparted to all business majors should be incorporated into the business core. Finance, business law, management and strategy will all be affected by the corporate governance provisions. An understanding of business processes can be discussed in the information systems course. Ethics and acceptance and responsibility for the financial statements can be introduced in the principles of accounting classes. Table 3 identifies the major sections of SOX and the impact on courses in the accounting and business curriculum. We have identified the impact on courses on a two point scale: Very Significant, which implies it should be thoroughly discussed in the class; and, Somewhat Significant, which implies it should be brought to the attention of students in the class.

There are eleven major title sections of SOX. These title sections and the subsections are identified in Table 2. A complete copy of the Act can be obtained at the SEC website listed in Table 1. Title I, Public Company Accounting Oversight Board, and Title II, Auditor Independence, of SOX will have a dramatic impact on accounting and auditing. The overall regulation of the public accounting environment has changed. The creation of the new Public Companies Accounting Oversight Board (PCAOB) and its new authority has produced an audit regulatory environment that is specific to publicly-held companies. The private sector companies and CPAs operating in that arena will follow a different set of standards. They will continue to follow the professional standards issues by the American Institute of CPAs (AICPA). This change causes a real shift in the content and focus of accounting and auditing classes because students need to be more aware than ever that the profession is now government regulated and not self regulated as it was in the past. The services CPAs can provide to their audit clients have shifted. Specifically, CPAs are prohibited from providing eight specific non-audit services to their audit clients. Services provided by the external auditor and other CPA firms must be preapproved by an audit committee. This area of the Act can influence both the finance and management courses since these areas deal with the revised roles of corporate governance and getting management to understand the role of an audit committee in its organization.

SOX and the new NYSE and NASDAQ listing standards affect the oversight role of corporate boards by regulating board composition, structure, and proceedings. The NYSE and NASDAQ listing requirements addressed board composition by (1) requiring that boards of listed companies have a majority of independent directors and (2) clarifying and tightening the definition of an independent director. SOX and the related SEC regulations use a different definition of independence that applies only to the audit committee. Both exchanges disqualify the following as "outside" directors: 
- $\quad$ Certain current and certain former employees and independent contractors;

- $\quad$ Certain employees of companies that make payments to, or receive payments from, the listed company for property or services in an amount which, in any single fiscal year, exceeds certain thresholds;

- $\quad$ Certain interlocking directors;

- $\quad$ Certain employees and partners of the company's auditors; and

- $\quad$ Certain family members.

SOX and the related listing standards changed the structure of the board by requiring certain wholly independent board committees. For example, audit committees must consist of at least three members, and every member must meet the independence rules mandated by the exchanges and the SEC. Both exchanges require that executive compensation decisions and board nominations be made (or at least recommended to the board) by independent directors only.

Corporate governance will also be affected by the procedural changes. The new listing rules require corporate boards to hold boards to conduct regular executive sessions without any managers in attendance. NYSE companies must also adopt and disclose corporate governance guidelines covering such areas as director's responsibilities, committee responsibilities, performance evaluation and management succession. The new NASDAQ requirements provide that the audit committee or some other group of independent directors must review and approve every "related party transaction.' NYSE and NASDAQ companies must adopt and disclose a corporate code of conduct and ethics. Corporate boards must approve the code and waivers for directors and executive officers.

These corporate governance changes have a widespread impact on business and accounting curriculums. An integrated or cross-disciplinary approach should be used to address these changes across the curriculum. Finance faculty will want to consider the implications these changes have when discussing the goal of the firm, agency theory, flotation costs (cost of going public), and possibly capital budgeting and cost of capital. Management faculty should look at these board changes from a legal and ethical perspective across the curriculum. Corporate strategy will also be affected by these changes. Some commentators have argued that the new rules will stifle innovation and risk taking.

Title III, Corporate Responsibility, of SOX requires the CEO and CFO to certify the fairness of the financial statements. This section makes it imperative that all business majors see the relevance of understanding financial statements. If a CEO and CFO certify that the financial statements are fairly presented, but the statements are later restated, the officers could possibly face criminal penalties. SOX requires the forfeiture of any bonuses or gains from sale of stocks if the financial statements require restatement. This knowledge is important to all business majors and should be covered somewhere in a finance, business law, or management course. The material in this section should be presented, and students should be familiar with it so that they know what their responsibilities will be as they progress up a corporate ladder.

Section 307, titled, Rules of Professional Responsibility for Attorneys, and the related SEC rules also changed the landscape for reporting corporate misconduct. For example, the new SEC rules require "up-the-ladder" reporting of corporate misconduct by outside counsel. Certain material violations must be reported to the chief legal counsel and/or its chief executive officer, and then to the audit committee if an appropriate response is not taken within a reasonable time.

Title IV, Enhanced Financial Disclosures, contains several important sections. The most significant section in this title deals with management's responsibility to assess internal control (Section 404). Section 404 requires (1) management to design and implement reliable internal financial controls, (2) management to assess to the reliability and effective functioning of those internal controls, and (3) the independent auditor of the financial statements to evaluate and assess the management's design, implementation, and assessment of the internal controls and further attest to the effectiveness of the foregoing statements made by management. The CEO and the CFO have to certify to the effectiveness of the organization's internal control system to prevent and detect material fraud and misrepresentation in the financial statements. As a result, managers will need more background in accounting than they needed before and a better understanding of business operations and processes. In the past, many companies failed to invest adequately in business processes and internal controls. Long term, corporate investment in business 
operations and processes and internal controls should translate into greater operating efficiency and possibly substantial cost savings. As a result, all business students - not just accounting majors - will need a better understanding of financial statements, business operations and process, and related internal controls. Also, the decision processes in an organization need to be fully understood and documented. Students will more fully understand the practical implications of decision and internal control processes after they reach the real world, but they need to understand the importance of decision and internal control processes in an organization. It is more important than ever that business schools begin to take a truly integrated (cross-disciplinary) approach to business issues for the benefit of all business majors. Cross-disciplinary faculty teams should be formed to address the issues raised by SOX and the related regulatory mandates. Information systems, accounting, operations management and finance courses must be integrated (linked to each other) to develop effective learning goals concerning decision making, business operations and processes, and internal controls affect performance and the financial statements, particularly the income statement. A common theme or thread that faculty may use to align these courses would be process or value-added analysis.

Another subsection in this area that has some significance is Section 406, Code of Ethics for Senior Management. All business courses should emphasize ethics and SOX stresses the implementation and enforcement of a code of ethics. The critical aspect of this section is the ability of organization to assure itself that its code of ethics is being followed. One can point to Enron who had a very strong code of ethics for its top management, but very little of their code was followed by senior management.

The remaining sections have significance to the business law and management courses. They stress the penalties that will occur to white collar criminals and violators of the SOX. Title VIII, Corporate and Criminal Fraud Accountability, has a section that describes the limitations on companies trying to restrict employees from trading in their own company securities, such as a $401 \mathrm{~K}$ plan. Every business major should have an understanding of how to manage their retirement accounts. This topic could be introduced in a finance course.

\section{CONCLUSION}

In conclusion, business and accounting curriculums are designed to educate and train future business professionals and leaders. When Congress passed SOX in 2002, it dramatically impacted the responsibilities of corporate executives and CPAs and consequently required corresponding changes in the business schools prepare students to assume these roles. Because the Act changed the manner in which corporate decisions are made and how corporate organizations are governed and because of its impact on corporate business and CPA firms, it required business schools to modify the curriculums in business and accounting. This paper demonstrated the impact on the undergraduate business and accounting programs. In most cases, it is suggested that SOX material be integrated into existing courses because of the various constraints on undergraduate programs.

\section{REFERENCES}

1. Bisoux, Tricia, The Sarbanes-Oxley Effect., BizEd, AACSB International, July/August 2005, Vol. IV, Issue 5, p24-29.

2. Block, Stanley B. The Latest Movement to Going Private: An Empirical Study. Journal of Applied Finance, Spring/Summer2004, Vol. 14,1, p36-44.

3. Why Controllers at Most Private Companies Are Not Voluntarily Complying With Sarbanes-Oxley. Controller's Report, Feb. 2005, 2: 1,p20-23.

4. $\quad$ Ernst \& Young, LLP. What Private Companies Need To Know About the Sarbanes-Oxley Act. Emerging and Growth Markets, 2004.

5. Most Private Companies Are Adopting Some Sarbanes-Oxley Provisions. Financial Analysis, Planning \& Reporting, Jan. 2005, Vol. 5, 1, p8.

6. Financial Executives International, FEI Special Survey on Sarbanes-Oxley Section 404 Implementation. Financial Executives International, March 2005.

7. Impact on Private Company Audits in Illinois. Practical Accountant, Nov. 2004, Vol. 37, 11, p6. 
8. Oshiki, Alan. High Compliance Costs Outweigh Benefits Say Investors, Broadgate Consultants, LLC, March 2005.

9. $\quad$ Rankin, Ken. Slowdown for SOX? Accounting Today, September 6, 2004, Vol. 18, 16, p1-2.

10. Read, William J.; Rama, Dasaratha V.; Raghunandan, K. Local and Regional Audit Firms and the Market for SEC Audits. Accounting Horizons, Dec2004, Vol. 18, 4, p241-254.

11. Robert Half International Inc., The Impact of Sarbanes-Oxley on Private Companies: Are the New Rules Giving Rise to a Universal Standard? July 2003.

12. Sarbanes-Oxley Act (SOA), Public Law No. 107-204, Washington, D.C.: Government Printing Office.

Table 1

SOX Related Websites

\begin{tabular}{||l|l||}
\hline \multicolumn{1}{|c|}{ Organization } & \multicolumn{1}{c||}{ Website } \\
\hline Securities and Exchange Commission & http://www.sec.gov/about/laws.shtml\#sox2002 \\
\hline American Institute of CPAs & http://www.aicpa.org/statelegis/index.asp \\
\hline $\begin{array}{l}\text { The Financial Executives } \\
\text { International }\end{array}$ & http://www.fei.org/advocacy/sarbanesoxley.cfm \\
\hline $\begin{array}{l}\text { The Public Companies Accounting } \\
\text { Board (PCAOB) }\end{array}$ & http://www.pcaobus.org/ \\
\hline PricewaterhouseCoopers-US PWC) & http://www.pwcglobal.com/us/eng/main/home/index.html \\
\hline KPMG-US & http://www.us.kpmg.com/index.asp \\
\hline Deloitte-US & $\underline{\text { http://www.deloitte.com/dtt/home/0,1044,sid\%253D2000,00.html }}$ \\
\hline Ernst \& Young-US & http://www.ey.com/global/content.nsf/US/Home \\
\hline
\end{tabular}

Table 2

The Table of Contents for SOX

Sec. 1. Short title; table of contents.

Sec. 2. Definitions.

Sec. 3. Commission rules and enforcement.

TITLE I-PUBLIC COMPANY ACCOUNTING OVERSIGHT BOARD

- $\quad$ Sec. 101. Establishment; administrative provisions.

- $\quad$ Sec. 102. Registration with the Board.

- $\quad$ Sec. 103. Auditing, quality control, and independence standards and rules.

- $\quad$ Sec. 104. Inspections of registered public accounting firms.

- $\quad$ Sec. 105. Investigations and disciplinary proceedings.

- $\quad$ Sec. 106. Foreign public accounting firms.

- $\quad$ Sec. 107. Commission oversight of the Board.

- $\quad$ Sec. 108. Accounting standards.

- $\quad$ Sec. 109. Funding.

TITLE II-AUDITOR INDEPENDENCE

- $\quad$ Sec. 201. Services outside the scope of practice of auditors.

- $\quad$ Sec. 202. Preapproval requirements.

- $\quad$ Sec. 203. Audit partner rotation.

- $\quad$ Sec. 204. Auditor reports to audit committees.

- $\quad$ Sec. 205. Conforming amendments.

- $\quad$ Sec. 206. Conflicts of interest.

- $\quad$ Sec. 207. Study of mandatory rotation of registered public accounting firms.

- $\quad$ Sec. 208. Commission authority.

- $\quad$ Sec. 209. Considerations by appropriate State regulatory authorities.

TITLE III-CORPORATE RESPONSIBILITY

- $\quad$ Sec. 301. Public company audit committees.

- $\quad$ Sec. 302. Corporate responsibility for financial reports.

- $\quad$ Sec. 303. Improper influence on conduct of audits. 
- $\quad$ Sec. 304. Forfeiture of certain bonuses and profits.

- $\quad$ Sec. 305. Officer and director bars and penalties.

- $\quad$ Sec. 306. Insider trades during pension fund blackout periods.

- $\quad$ Sec. 307. Rules of professional responsibility for attorneys.

- $\quad$ Sec. 308. Fair funds for investors.

TITLE IV-ENHANCED FINANCIAL DISCLOSURES

- $\quad$ Sec. 401. Disclosures in periodic reports.

- $\quad$ Sec. 402. Enhanced conflict of interest provisions.

- $\quad$ Sec. 403. Disclosures of transactions involving management and principal stockholders.

- $\quad$ Sec. 404. Management assessment of internal controls.

- $\quad$ Sec. 405. Exemption.

- $\quad$ Sec. 406. Code of ethics for senior financial officers.

- $\quad$ Sec. 407. Disclosure of audit committee financial expert.

- $\quad$ Sec. 408. Enhanced review of periodic disclosures by issuers.

- $\quad$ Sec. 409. Real time issuer disclosures.

TITLE V-ANALYST CONFLICTS OF INTEREST

- $\quad$ Sec. 501. Treatment of securities analysts by registered securities associations and national securities exchanges.

TITLE VI-COMMISSION RESOURCES AND AUTHORITY

- $\quad$ Sec. 601. Authorization of appropriations.

- $\quad$ Sec. 602. Appearance and practice before the Commission.

- $\quad$ Sec. 603. Federal court authority to impose penny stock bars.

- $\quad$ Sec. 604. Qualifications of associated persons of brokers and dealers.

TITLE VII-STUDIES AND REPORTS

- $\quad$ Sec. 701. GAO study and report regarding consolidation of public accounting firms.

- $\quad$ Sec. 702. Commission study and report regarding credit rating agencies.

- $\quad$ Sec. 703. Study and report on violators and violations.

- $\quad$ Sec. 704. Study of enforcement actions.

- $\quad$ Sec. 705. Study of investment banks.

TITLE VIII-CORPORATE AND CRIMINAL FRAUD ACCOUNTABILITY

- $\quad$ Sec. 801. Short title.

- $\quad$ Sec. 802. Criminal penalties for altering documents.

- $\quad$ Sec. 803. Debts nondischargeable if incurred in violation of securities fraud laws.

- $\quad$ Sec. 804. Statute of limitations for securities fraud.

- $\quad$ Sec. 805. Review of Federal Sentencing Guidelines for obstruction of justice and extensive criminal fraud.

- $\quad$ Sec. 806. Protection for employees of publicly traded companies who provide evidence of fraud.

- $\quad$ Sec. 807. Criminal penalties for defrauding shareholders of publicly traded companies.

TITLE IX-WHITE-COLLAR CRIME PENALTY ENHANCEMENTS

- $\quad$ Sec. 901. Short title.

- $\quad$ Sec. 902. Attempts and conspiracies to commit criminal fraud offenses.

- $\quad$ Sec. 903. Criminal penalties for mail and wire fraud.

- $\quad$ Sec. 904. Criminal penalties for violations of the Employee Retirement Income Security Act of 1974.

- $\quad$ Sec. 905. Amendment to sentencing guidelines relating to certain white-collar offenses.

- $\quad$ Sec. 906. Corporate responsibility for financial reports.

TITLE X-CORPORATE TAX RETURNS

- $\quad$ Sec. 1001. Sense of the Senate regarding the signing of corporate tax returns by chief executive officers.

TITLE XI-CORPORATE FRAUD AND ACCOUNTABILITY

- $\quad$ Sec. 1101. Short title.

- $\quad$ Sec. 1102. Tampering with a record or otherwise impeding an official proceeding.

- $\quad$ Sec. 1103. Temporary freeze authority for the Securities and Exchange Commission.

- $\quad$ Sec. 1104. Amendment to the Federal Sentencing Guidelines.

- $\quad$ Sec. 1105. Authority of the Commission to prohibit persons from serving as officers or directors.

- $\quad$ Sec. 1106. Increased criminal penalties under Securities Exchange Act of 1934.

- $\quad$ Sec. 1107. Retaliation against informants. 
Table 3

SOX Provisions and Impact on Curriculum

\begin{tabular}{|c|c|c|c|}
\hline Provisions of Sox & Topical subject & Possible Courses impacted & $\begin{array}{l}\text { Significance of Impact oN } \\
\text { Course** }\end{array}$ \\
\hline $\begin{array}{l}\text { TITLE I-PUBLIC } \\
\text { COMPANY ACCOUNTING } \\
\text { OVERSIGHT BOARD }\end{array}$ & $\begin{array}{l}\text { New Public Companies } \\
\text { Oversight Board (PCAOB) } \\
\text { created and oversight of public } \\
\text { accounting profession }\end{array}$ & Auditing course(s) & Very significant \\
\hline $\begin{array}{l}\text { TITLE II-AUDITOR } \\
\text { INDEPENDENCE }\end{array}$ & $\begin{array}{l}\text { Restriction of auditor services } \\
\text { provided to clients, approval of } \\
\text { auditors, and rotation of partners }\end{array}$ & $\begin{array}{l}\text { Auditing course(s) } \\
\text { Finance course(s) } \\
\text { Management course(s) }\end{array}$ & $\begin{array}{l}\text { Very significant } \\
\text { Somewhat significant } \\
\text { Somewhat significant }\end{array}$ \\
\hline $\begin{array}{l}\text { TITLE III-CORPORATE } \\
\text { RESPONSIBILITY }\end{array}$ & $\begin{array}{l}\text { Role of audit committees, CEO } \\
\text { and CFO certifications of } \\
\text { financial statements, influences } \\
\text { on external auditors, restriction } \\
\text { of trading of corporate securities, } \\
\text { restrictions of loans to officers, } \\
\text { and forfeiture of bonuses }\end{array}$ & $\begin{array}{l}\text { Auditing course(s) } \\
\text { Finance course(s) } \\
\text { Management course(s) } \\
\text { Business Law course(s) }\end{array}$ & $\begin{array}{l}\text { Very significant } \\
\text { Very significant } \\
\text { Very significant } \\
\text { Very significant }\end{array}$ \\
\hline $\begin{array}{l}\text { TITLE IV-ENHANCED } \\
\text { FINANCIAL DISCLOSURES }\end{array}$ & $\begin{array}{l}\text { Disclosures of off balance sheet } \\
\text { liabilities, disclosures of } \\
\text { transactions between } \\
\text { management and principal } \\
\text { stockholders, certifications of } \\
\text { internal control by CEO and } \\
\text { CFO, senior executives codes of } \\
\text { ethics, and audit expertise } \\
\text { disclosure }\end{array}$ & $\begin{array}{l}\text { Financial Accounting course(s) } \\
\text { Auditing course(s) } \\
\text { Finance course(s) } \\
\text { Management course(s) } \\
\text { Business Law course(s) } \\
\text { Accounting Information Systems } \\
\text { course } \\
\text { Information Systems course(s) }\end{array}$ & $\begin{array}{l}\text { Somewhat significant } \\
\text { Very significant } \\
\text { Somewhat significant } \\
\text { Somewhat significant } \\
\text { Somewhat significant } \\
\text { Very significant } \\
\text { Somewhat significant }\end{array}$ \\
\hline $\begin{array}{l}\text { TITLE V-ANALYST } \\
\text { CONFLICTS OF INTEREST }\end{array}$ & $\begin{array}{l}\text { Securities analysts roles with } \\
\text { company }\end{array}$ & Finance course(s) & Very significant \\
\hline $\begin{array}{l}\text { TITLE VI-COMMISSION } \\
\text { RESOURCES AND } \\
\text { AUTHORITY }\end{array}$ & SEC responsibility and authority & $\begin{array}{l}\text { Financial Accounting course(s) } \\
\text { Auditing course(s) } \\
\text { Finance course(s) }\end{array}$ & $\begin{array}{l}\text { Somewhat significant } \\
\text { Very significant } \\
\text { Somewhat significant }\end{array}$ \\
\hline $\begin{array}{l}\text { TITLE VII-STUDIES AND } \\
\text { REPORTS }\end{array}$ & $\begin{array}{l}\text { Studies and reports by the SEC } \\
\text { and PCAOB }\end{array}$ & $\begin{array}{l}\text { Financial Accounting course(s) } \\
\text { Auditing course(s) } \\
\text { Finance course(s) }\end{array}$ & $\begin{array}{l}\text { Somewhat significant } \\
\text { Somewhat significant } \\
\text { Somewhat significant }\end{array}$ \\
\hline $\begin{array}{l}\text { TITLE IX-WHITE- } \\
\text { COLLAR CRIME PENALTY } \\
\text { ENHANCEMENTS }\end{array}$ & White collar crime penalties & $\begin{array}{l}\text { Business Law course(s) } \\
\text { Management course(s) }\end{array}$ & $\begin{array}{l}\text { Very significant } \\
\text { Somewhat significant }\end{array}$ \\
\hline $\begin{array}{l}\text { TITLE X-CORPORATE } \\
\text { TAX RETURNS }\end{array}$ & $\begin{array}{l}\text { Senior executive (CEO and } \\
\text { CFO) potential responsibility for } \\
\text { corporate income tax returns }\end{array}$ & Income Tax course(s) & Somewhat significant \\
\hline $\begin{array}{l}\text { TITLE XI-CORPORATE } \\
\text { FRAUD AND } \\
\text { ACCOUNTABILITY }\end{array}$ & $\begin{array}{l}\text { Tampering with documents, } \\
\text { penalties under securities acts, } \\
\text { and restrictions to serve as senior } \\
\text { executive team member }\end{array}$ & $\begin{array}{l}\text { Business Law course(s) } \\
\text { Management course(s) }\end{array}$ & $\begin{array}{l}\text { Very significant } \\
\text { Somewhat significant }\end{array}$ \\
\hline
\end{tabular}

**Very Significant, which implies it should be thoroughly discussed in the class.

Somewhat Significant, which implies it should be brought to the attention of students in the class. 